\title{
Correction to: A new sea catfish, Netuma patriciae (Siluriformes: Ariidae), from the Philippines
}

\author{
Yumeka Takahashi $^{1} \cdot$ Seishi Kimura ${ }^{1} \mathbb{D} \cdot$ Hiroyuki Motomura ${ }^{2}$
}

Published online: 17 December 2019

(C) The Ichthyological Society of Japan 2019

\section{Correction to: Ichthyological Research https://doi.org/10.1007/s10228-019-00719-4}

The spelling of the third author name was incorrectly published. The correct author name is given in this Correction.

Publisher's Note Springer Nature remains neutral with regard to jurisdictional claims in published maps and institutional affiliations.

The original article can be found online at https://doi.org/10.1007/ s10228-019-00719-4.

Seishi Kimura

kimura-s@bio.mie-u.ac.jp

1 Graduate School of Bioresources, Mie University, 1577 Kurima-machiya-cho, Tsu, Mie 514-8507, Japan

2 The Kagoshima University Museum, 1-21-30 Korimoto, Kagoshima 890-0065, Japan 